\title{
ANALISIS PENERAPAN GOOD GOVERNANCE PADA PELAPORAN DAN PERTANGGUNGJAWABAN DANA DESA DI KECAMATAN PEUSANGAN KABUPATEN BIREUEN
}

\author{
Syarifah Rahmah ${ }^{1}$, Indayani ${ }^{* 2}$ \\ ${ }^{1,2}$ Program Studi Akuntansi Fakultas Ekonomi dan Bisnis Universitas Syiah Kuala \\ e-mail: syarifahrahmah.1997@gmail.com ${ }^{1}$,indayani@ unsyiah.ac.id ${ }^{2}$ \\ * Corresponding Author
}

\begin{abstract}
Abstrak
The purpose of this research is to see how the village government and village communities apply the principles of village financial management in reporting and accountability of village funds, as the implementation of good governance in several villages in Peusangan District, Bireuen Regency. The method used in this research is descriptive qualitative using interviews. Interviews were conducted with parties from the District, representatives of the village community, and village government, such as the Keuchik, the Village Secretary, the Head of Financial Affairs, the Representative of the BPD (Village Consultative Body) / Tuha Peut. The results of this study indicate that the application of the principles of village financial management in reporting and accountability of village funds in Peusangan District, Bireuen Regency has been implemented, but not yet fully implemented to the maximum.
\end{abstract}

Keywords: Good Governance, Reporting and Accountability of Village Funds, Village Financial Management Principles.

\section{Pendahuluan}

Desa memiliki kedudukan yang sangat penting, baik itu sebagai acuan untuk tercapainya tujuan pembangunan nasional maupun untuk lembaga pemerintahan negara Indonesia(Nafidah \& Anisa, 2017). Pemerintah desa memegang peran yang begitu penting agar terwujudnya suatu tata kelola pemerintahan yang baik di desa.Pemerintahan desa diselenggarakan oleh pemerintah desa.Pemerintah desa dapat dikatakan sebagai bagian dari birokrasi negara dan juga sebagai pemimpinlokal yang mempunyai peran dan posisi yang signifikan dalam mengelola dan membangun pemerintahan desa (Nafidah \& Anisa, 2017).

Dalam UU No. 6 Tahun 2014 Bab V Pasal 24 tentang Penyelenggaraan Pemerintahan Desa juga disebutkan bahwa "Penyelenggaraan pemerintah desa didasarkan pada beberapa asas, yakni: kepastian hukum, tertib penyelenggaraan pemerintahan, tertib kepentingan umum, keterbukaan, proporsionalitas, profesionalitas, akuntabilitas, evektivitas dan efesiensi, kearifan lokal, keberagaman, dan partisipatif". Pemerintah desa harus mampu mengelola keuangan desa yang telah ada dengan baik. Pengelolaaan keuangan desa yang baik dapat terwujud apabila pemerintah desa mau mengikuti peraturan yang telah ditetapkan sebagai pedoman dalam pengelolaan keuangan desa(Anifah et al., 2018).

Berbicara mengenai keuangan desa, tentu tidak lepas dengan namanya dana desa (DD). Dana Desa (DD) adalah dana yang bersumber dari Anggaran Pendapatan dan Belanja Negara yang diperuntukkan bagi desa yang ditransfer melalui Anggaran Pendapatan dan Belanja Daerah Kabupaten dan digunakan untuk membiayai penyelenggaraan pemerintahan, pelaksanaan pembangunan, pembinaan kemasyarakatan, dan pemberdayaan masyarakat (Utomo, Sudarmo, \& Suharto, 2018). Keberadaan dana desa disetiap desa diharapkan dapat merubah keadaan desa agar menjadi lebih baik serta kesejahteraan masyarakat desa dapat ditingkatkan.

Di Provinsi Aceh pada bulan September tahun 2018 belum ada satu desa pun yang mencairkan dana desa tahap III yang seharusnya secara umum sudah dapat dilakukan pencairannya sejak bulan juli tahun 2018. Bahkan, menurut Drs. Bukhari MM (Kepala Dinas Pemberdayaan Masyarakat dan Gampong 
(DPMG) Aceh), hingga kini, 30 gampong diantaranya malah belum menarik dana desa tahap I, begitu juga untuk tahap II, masih ada 1.770 gampong lagi yang belum mencairkan dana desa (Bakri,2018). Pasalnya hal ini disebabkan karena pihak gampong belum mempertanggungjawabkan penggunaan dana desa tahap sebelumnya, yakni jatah tahap I tahun 2018 belum bisa dicairkan jika belum mempertanggungjawabkan penggunaan dana desa tahun sebelumnya, begitu juga dengan dana desa tahap II dan III (Bakri, 2018). Salah satu kabupaten dari 23 kabupaten di Aceh yang belum mencairkan dana desa adalah Kabupaten Bireuen. Kabupaten Bireuen adalah kabupaten yang memiliki jumlah desa terbanyak setelah Kabupaten Aceh Utara dan kabupaten Pidie.Jumlah desa di Kabupaten Bireuen mencapai 609 desa dengan 17 Kecamatan (BPSBireuen, 2015).

Pada tahun anggaran 2018, dana desa terbanyak berada di Kabupaten Bireuen yang mencapai $\mathrm{Rp}$ 83,34 milyar dari pagu anggaran sebesar Rp 416,71 milyar (Fajri, 2018). Dilihat dari banyaknya dana desa yang didapatkan oleh Kabupaten Bireuen, seharusnya pemerintah desa sudah mampu memanfaatkan dana desa tersebut dengan semestinya sehingga peningkatan terhadap pembangunan dan kesejahteraan masyarakat desa pun tidak dapat dipungkiri dan diperlukannya penerapan prinsip good governance untuk tercapainya cita-cita tersebut serta dalam pelaporan dan pertanggungjawaban dana desa pun diperlukan prinsip tersebut.

Untuk mengantisipasi terjadinya hal tersebut, maka diperlukannya pemerintah desa yang memiliki keinginan untuk merubah desanya ke arah yang lebih maju dan mau memperhatikan tingkat kesejahteraan masyarakat desanya. Kepala Desa sebagai pemegang kekuasaan atas dana desa memiliki peran yang strategis atas dana desa (Permendagri No 113 Tahun 2014 tentang Pengelolaan Keuangan Desa), sehingga kepala desa harus mengetahui bagaimana pengelolaan keuangan desanya apakah sudah dikelola sebagaimana semestinya sesuai dengan Peraturan Menteri Dalam Negeri Nomor 113 Tahun 2014 tentang Pengelolaan Keuangan Desa, dalam hal ini yakni dana desa.

Permasalahan yang diangkat dalam penelitian ini ialah bagaimana analisis penerapan good governance pada pelaporan dan pertanggungjawaban dana desa di Kecamatan Peusangan Kabupaten Bireuen. Adapun tujuan penelitian yang ingin dicapai oleh peneliti dalam penelitian ini ialah untuk mengetahui bagaimana analisis penerapangood governancepada pelaporan dan pertanggungjawaban dana desa di Kecamatan Peusangan Kabupaten Bireuen, apakah telah dilakukan dengan semestinya.

\section{Kajian Pustaka \\ Desa}

Desa merupakan salah satu struktur pemerintahan yang ada di Indonesia. Desa dikenal dengan struktur pemerintahan yang sangat dekat dengan masyarakat (Anifah, Heriyanto, \& Muchid, 2018).Desa memiliki kedudukan yang sangat penting, baik itu sebagai acuan untuk tercapainya tujuan pembangunan nasional maupun untuk lembaga pemerintahan negara Indonesia (Nafidah \& Anisa, 2017).

Desa memiliki wewenang seperti yang telah dituangkan dalam UU Nomor 6 Tahun 2014 Tentang Desa, yaitu:

1) Kewenangan berdasarkan hak asal usul;

2) Kewenangan lokal berskala desa;

3) Kewenanganyang ditugaskan oleh Pemerintah, Pemerintah Daerah Provinsi, atau Pemerintah Daerah Kabupaten/Kota, dan wewenang lain yang ditugaskan oleh Pemerintah, Pemerintah Daerah Provinsi, atau Pemerintah Daerah Kabupaten/Kota, sesuai dengan ketentuan peraturan perundang-undangan.

\section{Pemerintah Desa}

Pemerintah desa merupakan penyelenggara urusan pemerintahan dan kepentingan masyarakat setempat dalam sistem pemerintahan Negara Kesatuan Republik Indonesia (Permendagri No. 113 tahun 2014 pasal 1). Dapat dikatakan bahwa keberhasilan suatu pembangunan desa sangat tergantung pada bagaimana pemimpin desanya melaksanakan tugas dan wewengannya.

Pelaksanaan pemerintahan yang baik selalu berpatokan pada tugas pokok dan fungsi yang diatur oleh peraturan yang ditentukan dan pelaksanaan 
tugas pokok dan fungsinya tergantung pihak pemimpinnya sendiri (Risyid 2000:48 dalam Soares et al., 2015). Pemerintah desa merupakan bagian dari penyelenggaraan pemerintah desa. Menurut Nurcholis (2011:138) dalam Sumargono (2013) pemerintah memiliki tugas pokok yaitu:

1) Menjalankan urusan rumah tangga, urusan pemerintah umum, membangun dan membina masyarakat.

2) Melaksanakan tugas pembantuan dari pemerintah, pemerintah provinsi dan pemerintah kabupaten.

\section{Pengelolaan Keuangan Desa}

Keuangan desa merupakan segala sesuatu yang berkaitan dengan kekayaan desa baik itu dalam bentuk uang maupun barang. Pemerintah desa harus mampu mengelola keuangan desa yang telah ada dengan baik. Pengelolaaan keuangan desa yang baik dapat terwujud apabila pemerintah desa mau mengikuti peraturan-peraturan yang telah ditetapkan sebagai pedoman dalam pengelolaan keuangan desa.

Dalam Peraturan Menteri Dalam Negeri Nomor 113 Tahun 2014 tentang Pengelolaan Keuangan Desa dijelaskan bahwa: "Pengelolaan keuangan desa merupakan keseluruhan kegiatan yang meliputi perencanaan, penganggaran, penatausahaan, pelaporan, pertanggungjawaban dan pengawasan keuangan desa". Hak otonom yang diberikan tersebut diharapkan agar desa mampu mengelola pembelanjaan anggaran dengan semestinya (Nafidah \&Anisa, 2017).

\section{Pelaporan Dan Pertanggungjawaban Keuangan Desa}

Dalam menjalankan tugas, wewenang, hak, dan kewajibannya dalam mengelola keuangan desa, kepala desa mempunyai tugas untuk menyampaikan laporan. Laporan ini disampaikan melalui camat kepada Bupati/Walikota dan juga kepada BPD, kemudian laporan ini juga bersifat periodik semesteran dan tahunan (Kirowati, Qimyatussa'adah, \& Sugiharto, 2015). Adapun rincian laporan tersebut sebagai berikut:

1) Laporan Sementara Realisasi Pelaksanaan APBDes.

2) Laporan Pertanggungjawaban Realisasi Pelaksanaan APBDes kepada Bupati/Walikota setiap akhir tahun anggaran.

3) Laporan Realisasi Penggunaan Dana Desa dilaporakan kepada Badan Permusyawaratan Desa (BPD).

4) Laporan Keterangan Pertanggungjawaban Realisasi Pelaksanaan APBDes yang terdiri dari Pendapatan, Balanja, dan Pembiayaan.

Berikut flowchart mengenai mekanisne pelaporan keuangan desa dapat dilihat pada Gambar dibawah ini.

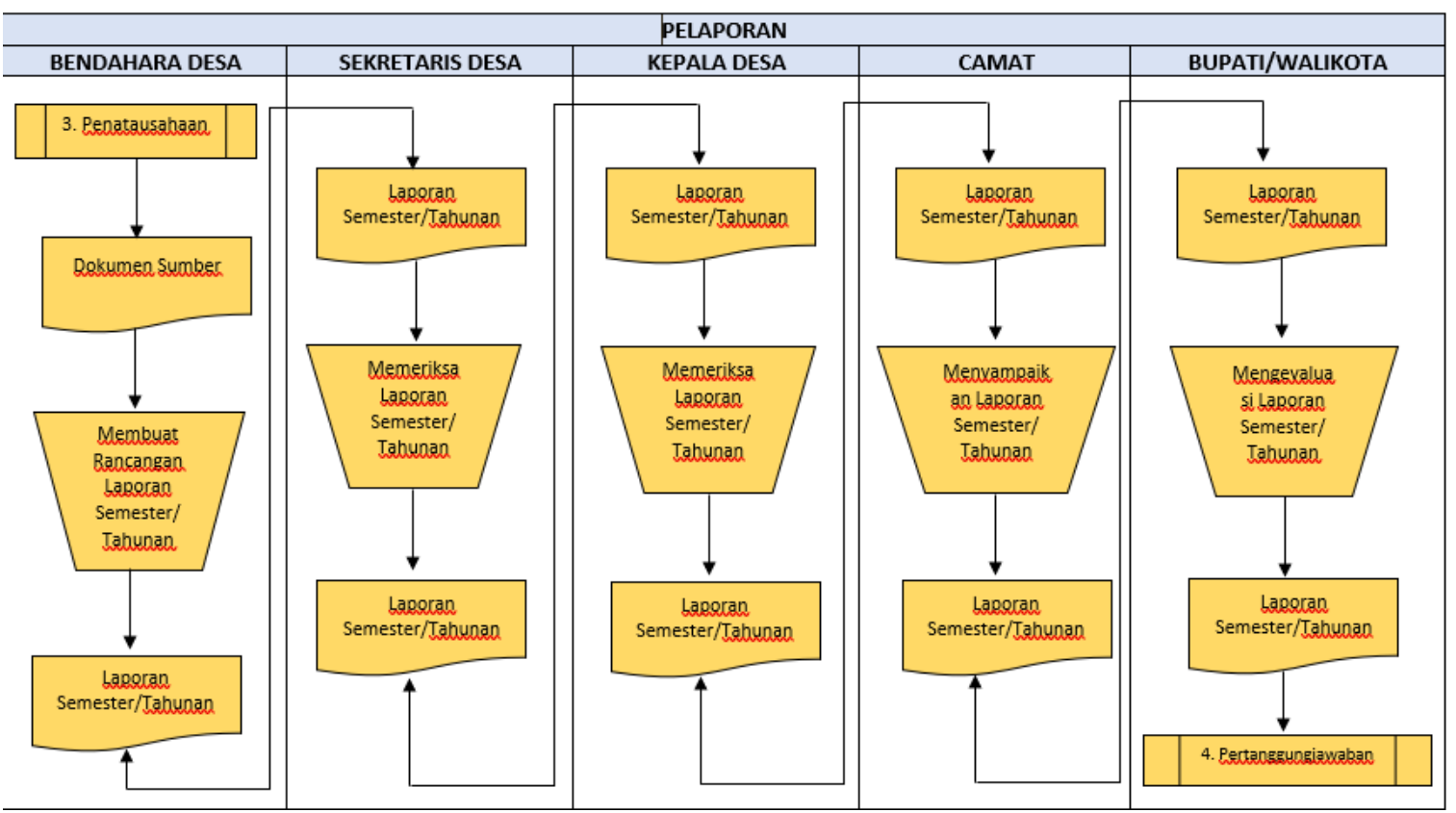

Sumber: Data Diolah (2019)

Gambar 1. mekanisne pelaporan keuangan desa 
Setelah tahap pelaporan dilanjutkan dengan tahap pertanggungjawaban. Tahap ini merupakan tahapan terakhir dalam pengelolaan keuangan desa. Tahap ini dilakukan pada setiap akhir tahun anggaran. Sama halnya dengan tahap sebelumnya, pemerintah desa memiliki tugas untuk mempertanggungjawabkan segala hal yang berhubungan dengan keuangan desa yakni dengan menyampaikan hasil Laporan Pertanggungjawaban kepada Bupati/Walikota melalui camat di setiap akhir tahun anggaran, dan penyampaian tersebut paling lambat satu bulan setelah akhir tahun anggaran yang sedang berjalan, tepatnya pada bulan januari tahun berikutnya (Mondale et al., 2017).

Adapun flowchart mengenai alur pertanggungjawaban keuangan desa dapat dilihat pada gambar berikut.

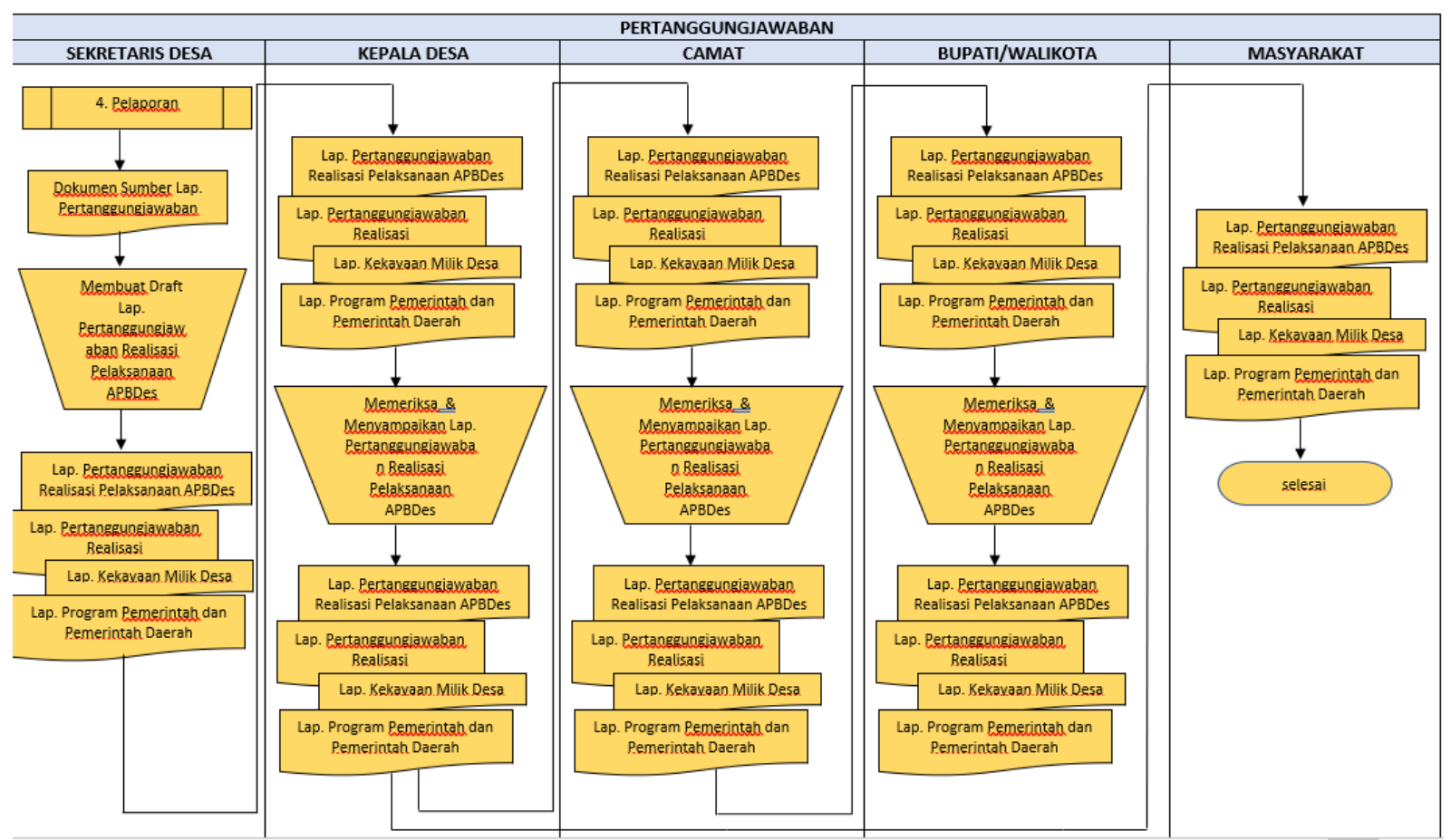

Sumber: Data Diolah (2019)

Gambar 2. mekanisne pertanggungjawaban keuangan desa

Ditetapkannya Undang-Undang No.60 Tahun 2014 tentang dana desa diharapkan dapat merubah keadaan desa agar menjadi lebih baik serta kesejahteraan masyarakat dapat ditingkatkan. Dana Desa (DD) adalah dana yang bersumber dari Anggaran Pendapatan dan Belanja Negara yang diperuntukkan bagi desa yang ditransfer melalui Anggaran Pendapatan dan Belanja Daerah Kabupaten dan digunakan untuk membiayai penyelenggaraan pemerintahan, pelaksanaan pembangunan, pembinaan kemasyarakatan, dan pemberdayaan masyarakat (Utomo et al., 2018).

Ketentuan yang mengatur tentang Dana Desa yaitu Peraturan Pemerintah Nomor 60 Tahun 2014 tentang Dana Desa yang bersumber dari Pendapatan dan Belanja Negara. Dalam PP tersebut telah disebutkan bahwa: "Dana Desa dikelola secara tertib, taat pada ketentuan peraturan perundang-undangan, efisien, ekonomis, efektif, transparan, dan bertanggung jawab dengan memperhatikan rasa keadilan dan kepatuhan serta mengutamakan kepentingan masyarakat setempat". Berdasarkan bunyi Peraturan Pemerintah tersebut, maka pemerintah desa diharuskan untuk memahami dan menerapkan tata cara pengelolaan keuangan desa yang baik sebagai perwujudan dari tata kelola pemerintahan yang baik (good governanace).

\section{Pelaporan Dan Pertanggungjawaban Dana Desa}

Dalam pengelolaan keuangan desa ada yang namanya dana desa. Dana desa merupakan salah satu komponen dalam struktur APBDeas. Sama 
halnya dengan pelaporan dan pertanggungjawaban keuangan desa, pelaporan dan pertanggungjawaban dana desa pun memiliki peratuan yang harus dipatuhi oleh pemerintah desa. Dalam menjalankan kewajiban, hak, tugas, dan wewenangnya dalam mengelola dana desa, kepala desa memiliki kewajiban untuk menyiapkan laporan yang memuat penggunaan dana desa untuk satu periode anggaran (Setiawan, 2018). Laporan ini bersifat periodik semesteran dan tahunan, yang disampaikan kepada Bupati/Walikota dan juga disampaikan kepada BPD (Kirowati et al., 2015).

Laporan yang harus disampaikan oleh pemerintah desa ini ialah Laporan Realisasi Penggunaan Dana desa.Laporan Realisasi Penggunaan Dana Desa dibagi menjadi dua semester, semester pertama dilaporkan paling lambat pada akhir bulan Juli tahun berkenan, sedangkan Laporan Realisasi Penggunaan Dana Desasemester akhir dilaporkan paling lambat pada bulan Januari ditahun berikutnya(Kirowati et al., 2015).

\section{Good Governance}

Agar terciptanya suatu tata kelola pemerintahan yang baik dalam pelaporan dan pertanggungjawaban keuangan desa, pemerintah desa memerlukan suatu pedoman yang dapat membawa mereka menuju ke arah yang lebih baik dalam mengelola keuangan desa. Dalam hal ini suatu desa yang baik dapat terwujud dengan diterapkannya prinsip good governanve dalam desa tersebut.

Untuk mewujudkan tata kelola yang baik dalam pelaporan dan pertanggungjawaban keuangan desa, prinsip good governance yang dibutuhkan hampir sama pada umumnya. Dalam pelaporan dan pertanggungjawaban keuangan desa ada empat prinsip atau asas yang menjadi pedoman pemerintah desa agar terwujudnya tata kelola pemerintahan yang baik. Sesuai dengan Peraturan Menteri Dalam Negeri Nomor 113 Tahun 2014 Tentang Pengelolaan Keuangan Desa menyebutkan bahwa: "Keuangan desa dikelola berdasarkan asas-asas transparansi, akuntabilitas, partisipasif serta dilakukan dengan tertib dan disiplin anggaran".

Asas dalam pengelolaan keuangan desa merupakan kunci utama agar terwujudnya tata kelola pemerintahan yang baik dalam pengelolaan keuangan desa. Terciptanya keuangan desa yang baik tergantung pada bagaimana cara pemerintah desanya dalam mengelola keuangan desa (Madea et al., 2017). Adapun Empat asas yang disebuatkan dalam Pemendagri Nomor 113 Tahun 2014 tersebut sebagai berikut.

1) Transparan

Maksud transparan dalam pengelolaan keuangan desa adalah pengelolaan keuangan desa tidak secara sembungi-sembunyi atau dirahasiakan dari masyarakat, dan harus sesuai dengan kaedahkaedah hukum serta peraturan yang ada.Apabila asas transparansi ini diterapkan, maka semua uang desa dapat diketahui dan diawasi oleh pihak yang berwenang.

2) Akuntabel

Akuntabel memiliki arti bahwa semua kegiatan yang dilakukan oleh pemerintah desa harus dapat dipertanggungjawabkan kepada pihak-pihak yang mempunyai hak dan

wewenang untuk meminta keterangan atas pertanggungjawaban.Dengan demikian, pemerintah desa yang bertugas dalam pelaksanaan kegiatan dan penggunaan anggaran harus mampu mempertanggungjawabkan dengan benar, dimulai dari tahap perencanaan hingga tahap pertanggungjawaban.

3) Partisipatif

Menerapkan asas partisipatif dalam pengelolaan keuangan desa maksudnya dalam setiap kegiatan yang dilakukan pemerintah desa harus mengikutsertakan atau melibatkan masyarakat desa baik itu secara langsung maupun tidak langsung melalui lembaga perwakilan masyarakat desa yang dapat menjadi tempat penyaluran aspirasi masyarakat, yakni Badan Permusyawaratan Desa (BPD), di provinsi Aceh lembaga ini disebut dengan sebutan Tuha Peut.

\section{4) Tertib dan Disiplin Anggaran}

Tertib dan disiplin anggaran maksudnya bahwa semua anggaran desa harus dikelola secara konsisten, dan pencatatan baik itu untuk pengeluaran ataupun penerimaan semuanya harus dicatat sesuai dengan prinsip akuntansi keuangan yang telah diterapkan di desa.Selain itu, agar terwujudnya keuangan desa yang tertib dan disiplin anggaran, maka pengelolaan keuangan desa harus taat hukum, tepat waktu, tepat jumlah, serta harus sesuai dengan prosedur yang telah ditetapkan. 


\section{METODE PENELITIAN}

Penelitian ini menggunakan pendekatan kualitatif, yaitu data yang dikumpulkan bukan berupa angka-angka, melainkan berasal dari wawancara dan dokumentasi resmi lainya (Amalia et al., 2017). Tujuan studi yang digunakan dalam penelitian ini bersifat studi deskriptif, yakni mendeskripsikan sejauh mana penerapan prinsip good governance dalam pelaporan dan pertanggungjawaban dana desa pada desa yang ada di Keucamatan Peusangan Kabupaten Bireuen. Pada penelitian ini prinsip good governance diambil dari asas-asas pengelolaan keuangan desa, yakni transparansi, akuntabilitas, partisipasi, serta tertib dan disiplin anggaran.

Strategi penelitian yang digunakan dalam penelitian ini yaitu strategi penelitian observasi langsung dan wawancara. Strategi penelitian observasi diartikan sebagai suatu tindakan berupa pengamatan, pencatatan, analisis dan interprestasi tingkah laku atau kegiatan yang direncanakan, dan strategi wawancara ialah suatu strategi yang digunakan dalam pengumpulan data yang efektif, terutama selama tahap penelitian eksploratif (Sekaran \& Bougie, 2017). Adapun pihak-pihak yang menjadi narasumber dalam penelitian ini adalah pemerintah desa seperti (Keuchik, Sekretaris Desa, Kaur Keuangan, Perwakilan BPD (Badan Permusyawaratan Desa)/ Perwakilan Tuha Peut), masyarakat desa, dan pihak dari kantor camat Kecamatan Peusangan.

\section{Objek Dan Lokasi Penelitian}

Objek penelitian atas pelaporan dan pertanggungjawaban dana desa ini ialah pelaporan dan pertanggungjawaban dana desa di tiga desa yang berlokasi di KecamatanPeusangan Kabupaten Bireuen, yaitu desa Cot Keuranji, Desa Blang Asan, dan Desa Pante Lhong.

\section{Jenis dan Sumber Data}

Jenis data yang diperlukan dalam penelitian ini yaitu data primer dan data sekunder. Data primer dalam penelitian ini didapatkan melalui observasi langsung, wawancara, dan dokumentasi. Data sekunder yang digunakan dalam penelitian ini didapatkan dari data yang dimiliki oleh pemerintahan desa yang menjadi objek dalam penelitian ini, seperti data jumlah penduduk Desa, data wilayah Desa, data laporan Realisasi Penggunaan Dana Desa, dan laporan pertanggungjawaban dana desa yang ada di Desa Cot Keuranji, Desa Blang Asan, dan Desa Pante Lhong.

\section{Teknik Pengumpulan Dan Analisis Data}

Pada umumnya ada beberapa teknik pengumpulan data dalam penelitian kualitatif. Dalam penelitian ini, Teknik pengumpulan data yang digunakan ialah observasi partisipasi pasif, wawancara, dan dokumentasi. Teknik analisis data dalam penelitian menggunakan kualitatif deskriptif. Yang mana, analisis dalam penelitian ini berfokus pada hasil pencapaian dalam penelitian yaitu sejauh mana penerapan prinsip good governance dalam pelaporan dan pertanggungjawaban dana desa.

\section{HASIL DAN PEMBAHASAN}

\section{Penerapan Prinsip Good Governance Pada Pelaporan Dan Pertanggungjawaban Dana Desa di Desa Cot Keuranji}

Berbicara mengenai penerapan good governance pada pelaporan dan pertanggungjawaban dana desa di Desa Cot keuranji, maka desa ini belum menerapkan sepenuhnya good governance tersebut, dalam hal ini adalah asas-asas pengelolaan keuangan desa yang menjadi acuan agar tata kelola pemerintahan yang baik dapat terwujudkan dalam pelaporan dan pertanggungjawaban dana desa di suatu desa. Belum maksimalnya penerapan asas-asas tersebut dapat dibuktikan dengan pernyataanpernyataan dari beberapa pihak yang menjadi narasumber, baik pihak di desa maupun di kecamatan.Ketidaktransparanan menjadi salah satu asas yang masih belum maksimal diterapkan oleh pemerintah desa desa Cot Keuranji. Yang mana, berdasarkan jawaban para narasumber bahwa Keuchik Desa Cot Keuranji tidak terbuka kepada masyarakat desanya mengenai pengelolaan dana desa. Setiap penggunaan dana desa seperti pengaspalan jalan dan pembelian lembu hingga penjualannya lagi, beliau melakukannya tanpa mengadakan musyawarah terlebih dahulu dengan perangkat desa lainnya dan juga dengan masyarakat desanya. Hal ini sesuai dengan pernyataan para narasumber sebagai berikut:

"Kami selalu berusaha untuk bekerja sesuai dengan aturan yang ada. Untuk berita yang beredar 
itu, keuchik bisa dikatakan tidak transparan dengan masyarakat desa mengenaipenggunaan dana desa, beliau tidak mau terbuka, seperti dana yang digunakan untuk membeli lembu, maunyakan diberitahukan kepada kami perangkat desanya dan juga masyarakat desanya penggunaan untuk pembelian lembu tersebut, walaupun lembu tersebut dibeli dan dijadikan penghasilan tambahan desa. Seperti uang kas desa, setau saya tidak dipengan oleh bendahara, tapi keuchik yang pegang.Saya juga tidak paham dengan perilaku beliau. Kalau untuk pelaporan, setiap kegiatan yang menggunakan dana desa kami selalu membuat laporan sesuai dengan yang telah ditetapkan. Kalau untuk keterlambatan pelaporannya kemarin itu, ya juga ada dikarenakan masalah keuchiknya itu, ada bentrok dengan Tuha Peut katanya beliau tidak menjelaskan dengan baik masalah penggunaan dana desa yang tahap III tahun anggaran 2018. Ya jadi, tertunda sebentar."(Hasil wawancara dengan Sekdes, pada tanggal 19 Juni 2019)

"Ya asas tersebut sudah diterapkan dengan baik.Partisipasi, tanggungjawab, disiplin waktu dan partisipansi. Ya, pak keuchik memang tidak terbuka dengan kami, seperti waktu lalu beliau menghabiskan dana sebanyak Rp 497.920.000,00 untuk pengaspalan jalan tahun anggaran 2018 yang dimulai pada tanggal 1 sampai tanggal 11 Agustus, beliau melakukannya tanpa musyawarah dengan kami. makanya masyarakat desa sering protes dengan keuchik yang sekarang." (Hasil wawancara dengan Tuha Peut, pada tanggal 21 Juni 2019)

Selain pernyataan yang telah dipaparkan oleh beberapa pemerintah desa diatas, ketidaktransparanan yang dilakukan oleh Keuchik desa Cot Keuranji juga dipaparkan oleh perwakilan masyarakat desa pada saat diwawancarai. Berikut paparan yang disampaikan oleh perwakilan masyarakat desa mengenai ketidaktransparanan pemerintah desa Cot Keuranji, mereka menyatakan bahwa:

"Menurut saya memang benar, Pak Keuchik tidak terbuka dalam mengelola dana desa, seperti kemarin itu Pak Keuchik ada melakukan pembelian lembu untuk desa, seharusnyakan beliau berbicara dulu dengan kami selaku masyarakat desanya, untuk siapa saja lembu tersebut diberikan untuk dipelihara, tetapi beliau malah tidak memberitahunya, tahu-tahu lembu tersebut sudah berada ditangan si pulan misalnya. Bukan tidak boleh si pulan yang mengurus lembu itu, tetapi setidaknya diberitahukan kepada masyarakat desanya, jadi kalau diberitahukan tidakakan terjadi salah paham atau akan enak sama enak." (Wawancara yang dilakukan dengan masyarakat desa, Pada Tanggal 8 Juli 2019)

Berdasarkan paparan yang telah disampaikan oleh perwakilan masyarakat desa diatas, dapat dilihat bahwa Keuchik desa Cot Keuranji masih belum menerapkan asas transparansi, Keuchik tersebut tidak melakukan musyawarah dengan masyarakat desa mengenai pengunaan dana desa seperti untuk pembelian hingga pemjualan kembali lembu tersebut. Walaupun telah ditempelnya papan pengumunan Anggaran Pendapatan dan Belanja Gampong (APBG) di Desa Cot Keuranji seperti pada gambar 3, masyarakat desa masih kurang puas dengan hal itu. Mereka menginginkan agar Keuchiknya tetap melakukan musyawarah dengan masyarakat desanya mengenai pertanggungjawaban atas semua kegiatan yang menggunakan dana desa, agar mereka lebih jelas mengetahui kemana saja dan untuk siapa saja dana desa tersebut disalurkan.

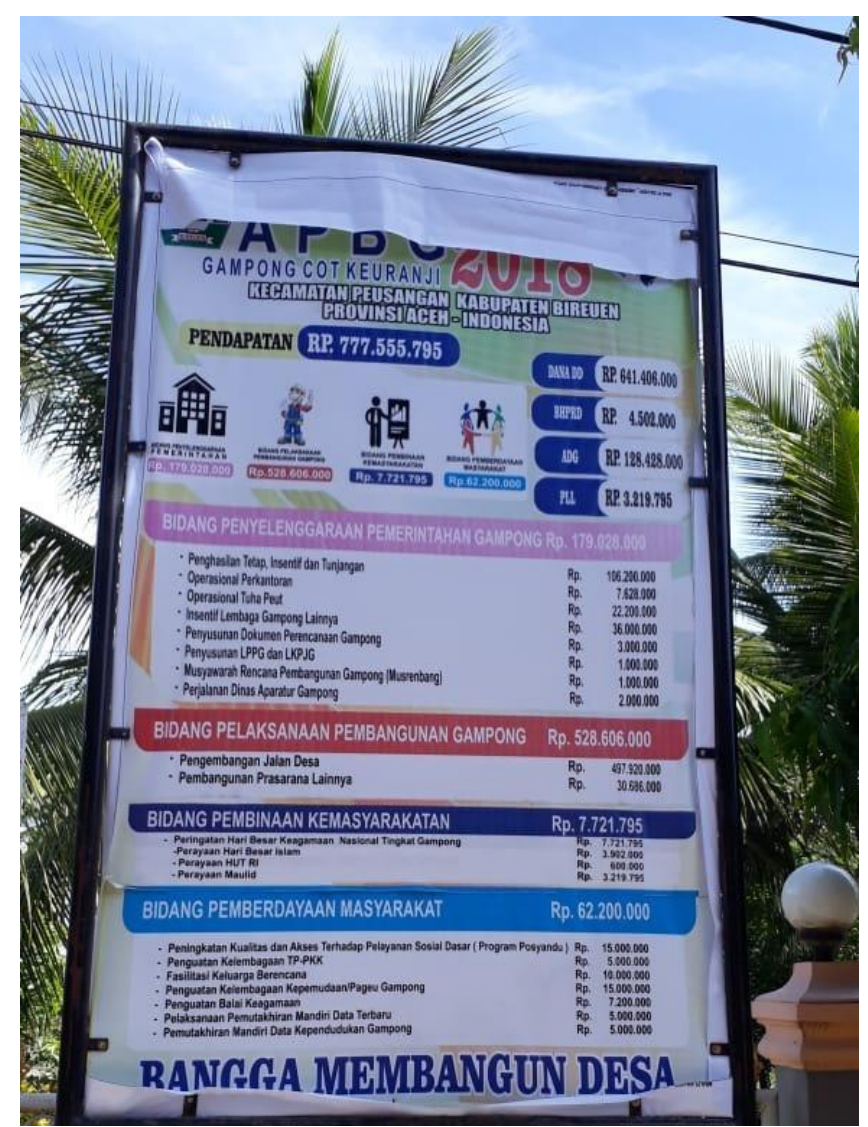

Sumber: Data Diolah(2019)

Gambar 3. Papan Pengumunan APBG Tahun 2018 
Selain asas transparansi yang belum maksimal penerapnnya, ada asas tertib dan disiplin anggaran yang juga masih belum maksimal penerapannya. Hal ini sesuai dengan ungkapan yang diberikan oleh pihak Kecamatan pada saat diwawancarai. Pihak kecamatan mengatakan bahwa ada beberapa desa yang terlambat dalam menyampaikan laporan pertanggungjawaban. Salah satunya desa Cot Keuranji. Desa ini termasuk desa yang terlambat dalam penyampaian laporan pertanggungjawaban, namun pihak kecamatan tidak mengetahui dengan jelas penyebab terlambatan tersebut. Pihak kecamatan tersebut juga menyebutkan selain desa Cot Keuranji, Desa Blang Asan pun termasuk desa yang terlambat dalam penyampaikan laporan pertanggungjawaban. Berikut penyataan yang disampaikan oleh pihak kecamatan saat diwawancarai:

"Kalau mengenai tidak tepat waktu, ada beberapa desa yang terlambat dalam melaporkan laporan pertanggungjawaban keuangan desanya kepada kami, seperti Desa Cot Keuranj dan Desa Desa Blang Asan.Seharusnya setiap laporan pertanggungjawaban sudah mereka berikan kepada kami sesuai waktu yang telah ditetapkan.Padalal setiap desa sudah diberikan TPK untuk membantu, Tetapi masih ada juga desa yang melewati waktu yang telah ditentukan tersebut. Pelaporan ke kecamatan saja sudah terlambat, ya pelaporan ke pihak Bupati/Walikota pun akan terlambat. Seharusnya pelaporan laporan pertanggungjawaban sudah bisa dilakukan sejak bulan juli 2018, tetapi hingga bulan September 2018 belum ada desa yang nyampaikannya.Padalah sejak bulan itu dana desa sudah bisa dicairkan. Apa mungkin ada kendala atau kesuliatan dalam pembuatan laporan, kami juga kurang tahu." (Hasil wawancara dengan Kasi PMG Kecamatan Peusangan, pada tanggal 11 Juli 2019)

Berdasarkan hasil pembahasan diatas, maka penyajian untuk hasil penelitian ini yang berisikan kesimpulan dari jawaban atas pertanyaan wawancara yang diajukan oleh peneliti kepada para narasumber dapat dilihat pada table 1 .
Tabel.1

Kesimpulan Hasil Penelitian Desa Cot Keuranji

\begin{tabular}{|c|l|l|}
\hline No & \multicolumn{1}{|c|}{ Asas } & \multicolumn{1}{|c|}{$\begin{array}{c}\text { Implementasi Good } \\
\text { Governance }\end{array}$} \\
\hline 1 & Asas Transparansi & Belum Maksimal \\
\hline 2 & Asas Partisipasi & Sudah Maksimal \\
\hline 3 & Asas Akuntabel & Sudah Maksimal \\
\hline 4 & $\begin{array}{l}\text { Asas Tertib dan } \\
\text { Disiplin Anggaran }\end{array}$ & Belum Maksimal \\
\hline
\end{tabular}

Sumber: Data Diolah (2019)

\section{Penerapan Prinsip Good Governance Pada Pelaporan Dan Pertanggungjawaban Dana Desa di Desa Blang Asan}

Dikaitkannya dengan proses pelaporan dan pertanggungjawaban dana desa di Desa Blang Asan, maka Desa Blang Asan sudah mengikuti asasasas tersebut, namun penerapannya masih belum maksimal. Masih terdapat asas yang belum diterapkan oleh pemerintah dan masyarakat desanya. Hal ini telah dibuktikan dengan beberapa pernyataan narasumber sebagai berikut:

"Sejauh ini sudah bagus dan baik.Hanya partisipasi masyarakat yang kurang diterapkan, dan untuk keterlambatan pelaporan LPJ memang iya desa kami telat melaporkannya.Ada sedikit kendala kemaren itu pada pembuatan laporannya." (Hasil wawancara dengan Keuchik, pada tanggal 11 Juni 2019)

"Pada umunnya sudah dijalankan.Hanya saja kalau berbicara mengenai partisipasi, masyarakat disini yang masih belum sesuai asas itu, seperti ukut hadir dalam musyawarah desa, masyarakat disini masih sangat kurang partisipasinya.Kemudian mengenai disiplin anggaran, memang untuk tahap III kemaren (2018) kami agak terlambat melaporkan, ada sedikit kendala pembuatan laporannya." (Hasil wawancara dengan Sekretaris Desa, pada tanggal 13 Juni 2019)

"Sampai saat ini sudah sesuai prosedur yang ditetapkan. Kami berusaha agar tata kelola pemerintahan yang baik dapat terwujudkan di desa Blang Asan ini apa lagi pada saat pelaporan dan pertanggungjawaban penggunaan dana desa. Mengenai laporan yang terlambat disampaikan itu, karena ada sedikit kendalam pada saat kami 
mempersiapkanlaporan pertanggungjawabannya." (Hasil wawancara dengan Kaur Keuangan, pada tanggal 15 Juni 2019)

Dari beberapa hasil wawancara yang telah disebutkan diatas, maka dapat dilihat bahwa untuk asas partisipasi masyarakat desa belum diterapkan dengan semestinya. Masih kurangnya partisipasi masyarakat untuk ikut serta dalam pengelolaan dana desa pada Desa Blang Asan. Hal ini menyebabkan terkadang masyarakat desa komplain dengan hasil dari program-program desa yang dianggap tidak sesuai dengan keinginan mereka, padalah pemerintah desa sudah membuat musyawarah desa dan mengundang masyarakat untuk hadir agar mereka bisa menanyai terkait materi LPJ hingga berpendapat.Inilah yang terkadang membuat konflik antara masyarakat dengan pemerintah desa.

Masih kurangnya penerapan asas-asas pengelolaan keuangan desa di Desa Blang Asan dapat mencerminkan belum terwujudknya tata kelola pemerintahan yang baik pada desa tersebut.Selanjutnya, penyajian untuk kesimpulan dari hasil penelitian ini yang berisikan jawaban dari pertanyaan wawancara yang diajukan oleh peneliti kepada para

narasumberdapat dilihat pada table 4.9.

Tabel 4.2

Kesimpulan Hasil Penelitian Desa Blang Asan

\begin{tabular}{|c|l|l|}
\hline No & \multicolumn{1}{|c|}{ Asas } & $\begin{array}{c}\text { Implementasi Good } \\
\text { Governance }\end{array}$ \\
\hline 1 & Asas Transparansi & Belum Maksimal \\
\hline 2 & Asas Partisipasi & Belum Maksimal \\
\hline 3 & Asas Akuntabel & Belum Maksimal \\
\hline 4 & $\begin{array}{l}\text { Asas Tertib dan } \\
\text { Disiplin Anggaran }\end{array}$ & Belum Maksimal \\
\hline
\end{tabular}

Sumber: Data Diolah (2019)

\section{Penerapan Prinsip Good Governance Pada Pelaporan Dan Pertanggungjawaban Dana Desa di Desa Pante Lhong}

Penerapan asas pengelolaan keuangan desa pada Desa Pante Lhong, berbeda hal nya dengan penerapan asas pengelolaan keuangan desa pada Desa Cot Keuranji dan Desa Blang Asan.Pada Desa Pante Lhong penerapan asas tersebut sudah dijalankan dengan baik. Hal ini dapat dibuktikan dengan beberapa jawaban dari hasil wawancara dengan para narasumber pada desa tersebut. Adapun jawabannya sebagai berikut:

"Yang pertama sejauh ini kami selalu berusaha untuk bekerja sesuai dengan aturan yang ada. Kedua kami selalu transparan kepada masyarakat mengenai penggunaan dana desa, ketiga setiap kegiatan yang menggunakan dana desa kami selalu membuat laporan sesuai dengan yang telah ditetapkan. Yang pasti akuntabel lah." (Hasil wawancara dengan Sekretaris Desa, pada tanggal 14 Juni 2019)

"Alhamdulillah walaupun dana desa ini dapat dikatakan hal yang baru diluncurkan kedesa-desa tepatnya tahun 2015, sejauh ini kita sudah menjalankannya dengan mengikuti aturan yang telah ditetapkan. Apalagi mengenai 4 asas tersebut, kita selalu berusaha agar tidak menyimpang darinya."(Hasil wawancara dengan Kaur Keuangan, pada tanggal 17 Juni 2019)

"Dalam hal ini, kami selalu berusaha.Pada prinsipnya kami selalu mengikuti asas pengelolaan keuangan desa yang transparansi, jujur, serta pertanggungjawaban terhadap masyarakat desa."(hasil wawancara Dengan Keuchik, pada tanggal 20 Juni 2019)

"Transparansi, pertanggungjawaban, pertisipasi, seтua sudah dijalan oleh perangkat Desa Pante Lhong ini.Seperti setiap ada pengadaan rapat mengenai program desa, selalu mengikutsertakan masyarakat desa."(Hasil wawancara dengan Tuha Peut, pada tanggal 20 Juni 2019)

Dari beberapa pernyataan narasumber diatas, maka dapat dikatakan bahwa Desa pante Lhong telah menerapkan asas-asas pengelolaan keuangan desa dengan baik. Desa Pante Lhong telah menjukkan adanya komitmen yang tinggi untuk menjalankan tanggungjawab sesuai dengan aturan yang sudah ditetapkan. Pada tahap pelaporan dan pertanggungjawaban dana desa mereka selalu berusaha agar tidak menyimpang dari asas pengelolaan keuangan desa. Seperti pada asas transparansi, pemerintah Desa Pante Lhong selalu transparans kepada masyarakat desanya, mereka membuat papan pengumuman mengenai APBG seperti pada gambar 4 yang didalamnya tercantum juga mengenai dana desa. Sehingga masyarakat desa bisa dengan mudah mengetahui kemana saja aliran dana 
desa tersebut. Kemudian untuk asas partisipasi, keikutsertaan masyarakat desa dalam pertanggungjawaban penggunaan dana desa juga baik, seperti pada saat diadakan musyawarah desa, masyarakat Desa Pante Lhong juga ikut berperan.

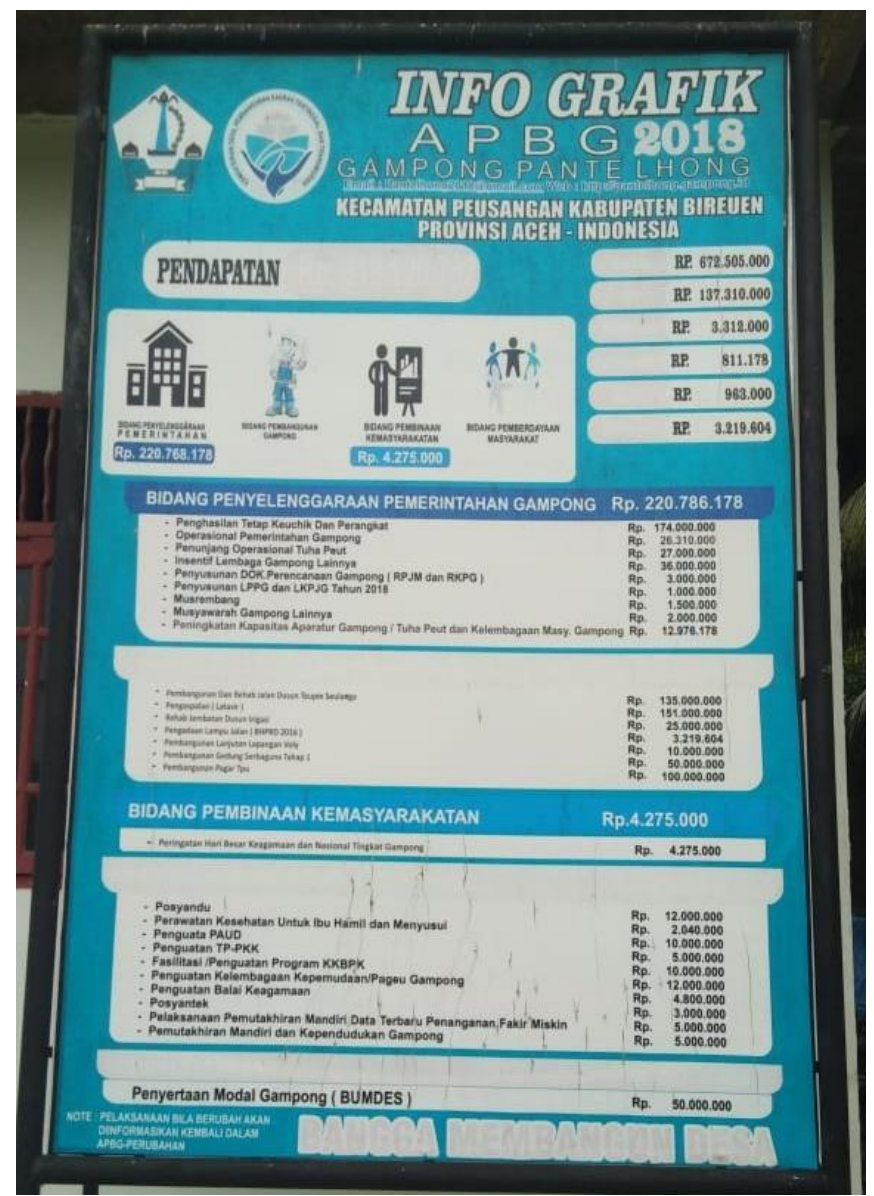

Sumber: Data Diolah(2019)

\section{Gambar 4. Papan Pengumuman APBG Tahun 2018}

Selanjutnya mengenai asas akuntabel, sesuai dengan pernyataan yang telah disampaikan oleh pihak Kecamatan (Kasi PMG) pada saat diwawancarai bahwa untuk asas ini pemerintah Desa Pante Lhong sudah menerapkannya dengan baik, mereka dapat mempertanggungjawabkan hasil penggunaan dana desa kepada Kecamatan dan Bupati/Walikota. Yang mana, penyampaian kepada Bupati/Walikota dilakukan melaui camat.

Penerapan asas-asas pengelolaan keuangan desa yang sudah diterapkan oleh masyarakat Desa Pante Lhong dapat mewujudkan terciptanya tata kelola pemerintahan yang baik di desa tersebut. Karena, untuk membangun suatu desa agar desa tersebut menjadi desa dengan tata kelola pemerintahan yang baik harus dimulai dari keinginan masyarakat desa itu
sendiri.Berikut ini penyajian mengenai kesimpulan dari hasil penelitian yang yang telah

dilakukan dapat dilihat pada tabel 4.10.

Tabel 4.3

Kesimpulan Hasil Penelitian Desa Pante Lhong

\begin{tabular}{|c|l|c|}
\hline No & \multicolumn{1}{|c|}{ Asas } & $\begin{array}{c}\text { Implementasi Good } \\
\text { Governance }\end{array}$ \\
\hline 1 & Asas transparansi & Sudah Maksimal \\
\hline 2 & Asas Partisipasi & Sudah Maksimal \\
\hline 3 & Asas Akuntabel & Sudah Maksimal \\
\hline 4 & $\begin{array}{l}\text { Asas Tertib dan } \\
\text { Disiplin Anggaran }\end{array}$ & Sudah Maksimal \\
\hline
\end{tabular}

Sumber: Data Diolah(2019)

\section{KESIMPULAN, KETERBATASAN, DAN SARAN}

Berdasarkan hasil penelitian dan deskripsi hasil wawancara yang sudah dijelaskan sebelumnya, maka dapat disimpulkan bahwa penerapan asas-asas pengelolaan keuangan desa agar terciptanya tata kelola pemerintahan yang baik (good governance) dalam pelaporan dan pertanggungjawaban dana desa di Kecamatan Peusangan Kabupaten belum sepenuhnya diterapkan dengan maksimal, masih ada desa-desa yang belum menerapkan asas-asas pengelolaan keuangan desa dengan semestinya sesuai dengan Peraturan Menteri Dalam Negeri Nomor 113 Tahun 2014 Tentang Pengelolaan Keuangan Desa, baik itu oleh pemerintah desa maupun masyarakat desanya. Hal ini telah digambarkan oleh beberapa desa yang ada di Kecamatan Peusangan Kabupaten Bireuen.Yang mana, dari tiga desa yang dijadikan objek penelitian dalam penelitian ini, dua desa masih belum maksimal dalam menerapkan asas-asas tersebut, sedangkan satu desa lainnya sudah menerapkan asas-asas tersebut dengan semestinya.

\section{Saran}

\section{Saran Akademis}

1) Agar penelitian dikatakan lebih representatif, bagi peneliti selanjutnya diharapkan agar memperluas objek dalam penelitiannyaa gar peneliti memiliki cakupan yang luas dan mampu memberi hasil penelitian yang lebih baik. Sehingga, penelitian tersebut dapat 
dikatakan lebih representafif.

2) Penelitian ini bersifat studi eksploratif, yang mana dalam penelitiannya tidak memutup kemungkinan terdapat persepsi yang berbeda dengan keadaan yang sebenarnya dari narasumber pada objek penelitian ini.

\section{Saran Praktis}

1) Bagi pemerintah desa yang belum menerapkan asas-asas pengelolaan kauangan desa dalam mengelola keuangan desa khususnya dalam pelaporan dan pertanggungjawaban dana desa, agar bisa mulai menerapkan asas- asas tersebut. Sehingga tata kelola pemerintahan yang baik (good governance) dapat terbentuk dalam desanya.

2) Kemudian juga, bagi masyarakat desa yang belum menerapkan asas-asas pengelolaan keuangan desa, seperti partisipasi masyarakat dalam musyawarah desa, sebaiknya untuk mulai ikut serta dalam mengelola keuangan desa, dengan bersama-sama menjaga dan menerapkan asas-asas tersebut, maka tata kelola pemerintahan yang baik dapat terciptakan dalam suatu desa

\section{Daftar P}

Amalia, R., \& Nadirsyah. (2017). Penerapan Peraturan Menteri Dalam Negeri Nomor 113 Tahun 2014 Tentang Pengelolaan Keuangan Desa ( Studi Pada Desa Di Kecamatan Tapaktuan Kabupaten Aceh Selatan ). Jurnal Ilmiah Mahasiswa Akuntansi, 2(3), 121-132.

Anifah, Heriyanto, M., \& Muchid. (2018). Pengelolaan Keuangan Desa Dalam Mewujudkan Good Governance. Jurnal Ilmu Administrasi Negara, 14(4), 395-400.

Badan Pusat Statistik Kabupaten Bireuen. (2015). Jumlah Kemukiman, Gampong Menurut Kecamatan Dalam Kabupaten Bireuen Tahun 2014. Diakses 03 Januari 2019. (https://bireuenkab.bps.go.id/statictable/2015/12 /23/47/jumlah-kemukiman-gampong- menurutkecamatan-dalam-kabupaten-bireuen-tahun 2 014.html)

Bakri. (2018).Dana Desa Aceh $R p \quad 14,8$ T. Diakses 22 Desember 2018. (http://aceh.tribunnews.com/2018/11/07/dana- desa-aceh-rp-148-t).

Bakri. (2018).Semua Gampong Belum Cairkan Dana Desa. diakses 24 Desembar 2018. (http://aceh.tribunnews.com/2018/09/06/se mua-gampong-belum-cairkan-dana- desa).

Cimahi, B. (2015). Pengelolaan Keuangan Desa:Sistem dan Prosedur Pelaporan Keuangan Desa. Diakses 17

Maret 2019.

(https://bppk.kemenkeu.go.id/id/publikasi/artike 1/147-artikel-anggaran-dan-

perbendaharaan/20473-pengelolaan-keuangan-

desa-sistem-dan-prosedur-pelaporan- keuangandesa).

Cimahi, B. (2015). Pengelolaan Keuangan Desa : Sistem dan Prosedur Pertanggungjawaban Keuangan Desa. Diakses 17 Maret 2019. (https://bppk.kemenkeu.go.id/id/publikasi/artike 1/147-artikel-anggaran-danperbendaharaan/20477-pengelolaan-keuangandesa-sistem-dan-prosedurpertanggungjawaban-keuangan-desa).

Kirowati, D., Qimyatussa'adah, \& Sugiharto. (2015). Penerapan Azas Pengelolaan Keuangan Desa (Studi Kasus: Desa Temboro Kecamatan Karas Kabupaten Magetan). Biomass Chem Eng, 49(23-6).

Madea, Y., Laloma, A., \& Londa, V. Y. (2017). Peran Kepala Desa Dalam Pengelolaan Dana Desa Di Kecamatan Essang Selatan Kabupaten Kepulauan Talaud. Jurnal Administrasi Publik, 3(046)

Mondale, T. F., Aliamin, \& Fahlevi, H. (2017). Analisis Problematika Pengelolaan Keuangan Desa ( Studi Perbandingan pada Desa Blang Kolak I dan Desa Blang Kolak II , Kabupaten Aceh Tengah ). Jurnal Perspektif Ekonomi Darussalam, 3(2), 196-212.

Nafidah, L. N., \& Anisa, N. (2017).Akuntabilitas Pengelolaan Keuangan Desa di Kabupaten

Jombang.Akuntabilitas, $\quad$ 10(2), 273-288. https://doi.org/ 10.15408/akt.v10i2.5936

Republik Indonesia. (2014). Undang-Undang Nomor 6 Tahun 2014 tentang Desa. (2014). Peraturan Pemerintah Nomor 43 Tahun 2014 tentang Peraturan Pelakasanaan Undang-Undang Nomor 60 Tahun 
2014.

. (2014). Peraturan Pemerintah Nomor 60

Tahun 2014 tentang Dana Desa.

$$
\text { (2014). Peraturan Menteri Dalam }
$$

Negeri Nomor 113 tahun 2014 tentang Pengelolaan Keuangan Desa.

Sekaran, U., \& Bougie, R. (2007). Metode Penelitian untuk Bisnis (6th ed.). Jakarta: Selemba Empat.

Setiawan, A. (2018). Pengelolaan Alokasi

Dana Desa Dalam Mewujudkan Good Governance. Among Makarti, 11(22), 23-36.

Soares, A., Nurpratiwi, R., \& Makmur, M. (2015). Peranan Pemerintah Daerah Dalam Perencanaan Pembangunan Daerah. Jurnal Ilmu Sosial Dan Ilmu Politik, 4(2), 231-236. https://doi.org/10.1007/s13398-014-0173-7.2

Utomo, kabul setio, Sudarmo, \& Suharto, didik G. (2018). Analisis Good Governance

Dalam Pengelolaan Keuangan Desa. Spirit Publik, $3(1), 50-66$. 